\title{
The Brazilian Blue Amazon under threat: Why has the oil spill continued for so long?
}

\author{
Leandra R. Gonçalves \\ DG Webster \\ Oran Young \\ Marcus Polette \\ Alexander Turra
}

${ }^{1}$ São Paulo University, SP, Brazil.

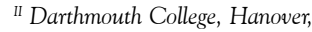
NH, United States.

(D) III University of California Santa Barbara, CA, United States.

IV Vale do Itajaí University, SC, Brazil

${ }^{\vee}$ São Paulo University, SP, Brazil.

\begin{abstract}
In August 2019, an oil spill incident washed the coast in Brazil affecting some of the country's most visited and preserved beaches in Northeast and Southeast. This paper argues that the influence of power disconnects delayed the proper actions. Power disconnects occur when the victims of environmental harm (residents of northeastern and southeastern Brazil) lack power to prevent it or, conversely, when those who do have the power to protect the environment (the Brazilian government and the international community) do not experience the costs of degradation. Although Brazil has emerged as an environmental leader in the international arena in the past, it has fallen behind on the improvements that are needed to prevent spills like this from affecting coastal communities and biodiversity in the future. Ultimately, as long as political injustices persist, ecological disasters will continue, and Governance will not improve.
\end{abstract}

Keywords: Oil spill; power disconnects; Brazil

São Paulo. Vol. 23, 2020

Debating Ideas

DOI: http://dx.doi.org/10.1590/1809-4422asoc20200077vu2020L5ID 


\section{Introduction}

For more than four months, oil has been washing up on beaches in Brazil, contaminating approximately $2,900 \mathrm{~km}$ of the most biodiverse and touristic coastal areas in the country. So far, the spill source is unknown (Figure 1). Government, researchers and civil society sources report that this is the worst environmental crisis ever to threaten the Brazilian coast, reaching more than 860 localities and with over 7000 tonnes of oil already removed from beaches by local groups (IBAMA 2019; OPEN LETTER FROM CIVIL SOCIETY, 2019'; SOARES et al., 2020). That is just the amount that could be removed; the volume that remains in the ocean or in inaccessible areas is likely much greater. About 10 months have passed since the first oil stains appeared on the northeastern coast, however, in June 2020, oil was seen again on the beaches in at least five Brazilian states (DIARIO DO NORDESTE, 2020). Known ecological effects are restricted to scores of dead marine mammals, sea turtles, and seabirds, and the potential impacts in specific environments, such as estuaries, mangroves, and seagrass meadows (MAGRIS; GIARRIZZO, 2020). Socioeconomic impacts have not be estimated, but include loss of revenue from tourism and fishing, loss of jobs and livelihoods, and the immediate consequences for human health (ARAUJO et al., 2020). While the amount of oil discovered so far is small compared to catastrophic spills like the BP Horizon, the area affected is immense and ecologically valuable. Why then has the crisis continued for so long and scaled up to a national disaster?

The answer seems to lie in the influence of power disconnects, which occur when the victims of environmental harms (residents of northeastern and southeastern Brazil) lack power to prevent it or, conversely, when those who do have power to protect the environment (the Brazilian government and the international community) do not experience the costs of degradation. Power disconnects are often self-reinforcing so they persist as an environmental problem gets worse, leading to structural injustices as well as environmental devastation (WEBSTER, 2015). In the case of the oil spill in Brazil, the main affected region (Northeastern coast) is an area that is historically marginalized and which did not support the current president in the 2018 election (ROSSI, 2018). Considering the hypothesis of power disconnect, one would expect a strong local response from the affected communities (within the limits of their capacity) and a weak national response.

This episode also illustrates an additional dimension of power disconnect, between the local communities and the governance of the Areas Beyond National Jurisdictions. Most evidence presented by the government suggests that the oil originated from a ship flagged by a foreign country in international waters. The spill itself, then, is not a failure of Brazilian policies only but is under the responsibility of the international community as a whole, which does not directly engage local communities in the governance process. Coastal residents of Brazil have little to say in the international negotiations that shape governance of marine pollution. Oil companies, shipping conglomerates, and national governments control negotiations. However, these stakeholders lack the incentives to

1. To date 84 institutions and 138 citizens have signed the letter demanding transparency and the end of classified documents to the government. 
effectively reduce this global environmental problem. To improve oil governance, the Brazilian government should actively act on the adequacy of preparedness and responsiveness to such disasters, engaging different social sectors, as well as invest on the negotiation and implementation of international agreements to improve the oil spill prevention in areas beyond national jurisdiction and on its own waters.

Figure 1: Oil tar occurrence in Brazilian Northeast coast. Source: Ibama/ NMI-CE, Ibama/Siscom, IBGE. The illustrative origin is just an estimate

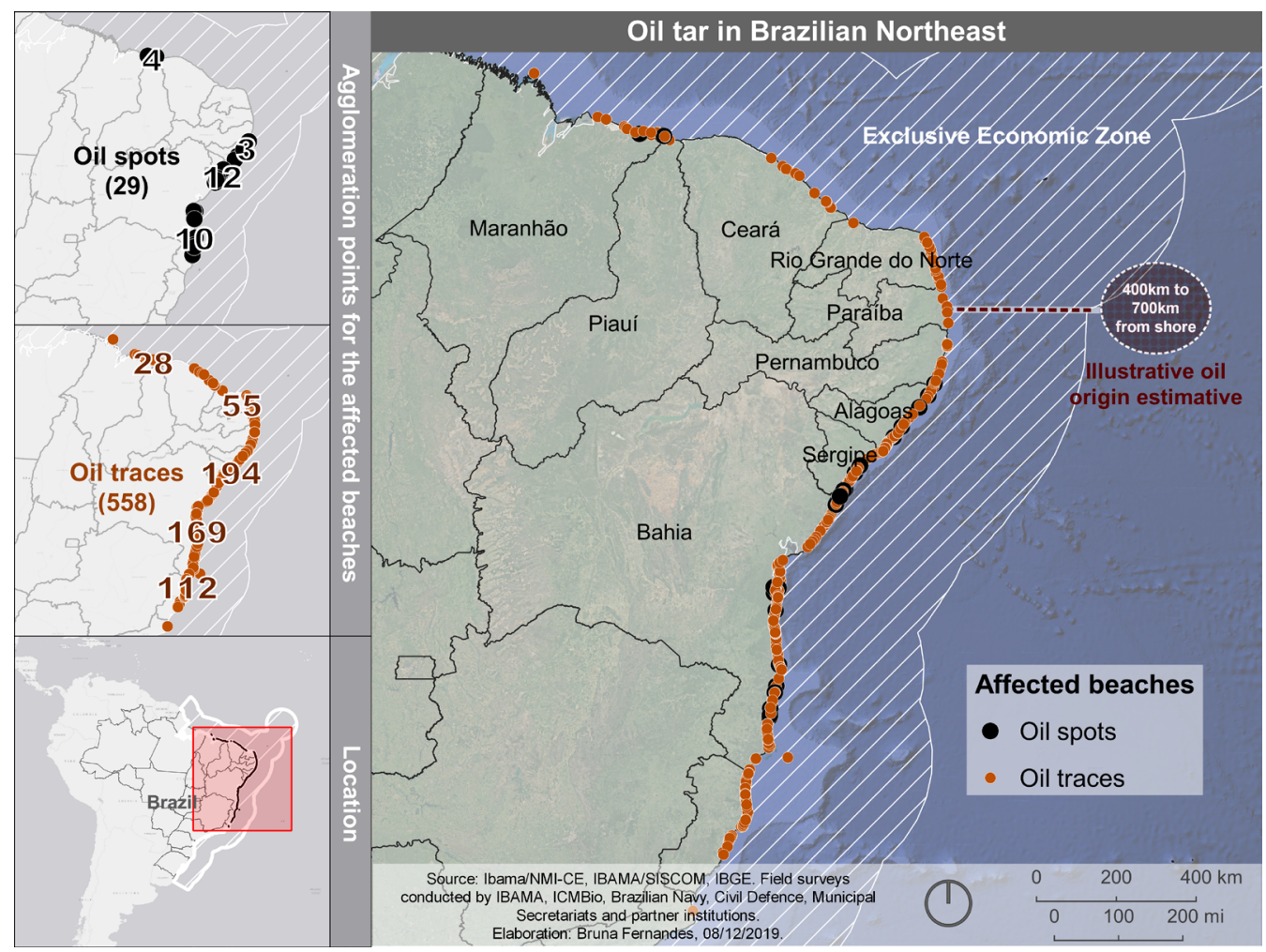

Source: IBAMA. Elaboration: Bruna Fernandes (30/10/2019).

\section{Local Governance}

When local communities noticed oil tar on their beaches, they rapidly created a collaborative network to clean up the oil using all of the resources they had at hand. They used social networks to organize themselves, share information, and raise funds. Local communities also organized to pressure the local and national governments for assistance by issuing letters of complaint and protesting at the Ibama regional headquarters (BATISTA, 2019). 
Evidences from the oil spill in Brazil supports the assertion that people who are most affected by the crisis will do the most that they can to solve the problem. The relative success of these local responses indicates that communities are critical to improve preparedness and responsiveness to oil spills, even more if they are an incorporated partner in a coordinated response from government and/or control over the source and/or possess sufficient resources to clean it up (WALKER et al., 2015). However, communities in Northeastern Brazil lacked sufficient capacity to fully mitigate the spill (e.g. cleaning up oil in the ocean or on the ocean floor or locating, isolating, and stopping the leak at it sources). They did not have the infrastructure necessary; they had no previous information to anticipate the spill or equipment to protect themselves while cleaning up contaminated areas. For this, they would need resources and support from the national government.

\section{National Government}

The government's failure to adequately prepare for and respond to this particular oil spill demonstrates marked indifference to the Northeastern region as well as the environment, more generally. It is particularly interesting that their early response was minimal but that once domestic and international outcry over the ongoing crisis reached their political power base, they began waging a war of information, making claims that were refuted by people on the ground or by the international press. The current government of Brazil has made it clear that environmental protection is not a priority through both words and actions, such as the gutting of environmental management capacity in a number of agencies (VIOLA; GONÇALVES, 2019).

The Brazilian government asserts that they have been acting in situ since the beginning of the oil spill (ESTADÃO, 2019), however important federal level actions were delayed. The first press release found in the Ibama website was from September $25^{\text {th }}$ (IBAMA, 2019), almost a month after the first discovery of oil in the region at the end of August. According to official records, the Brazilian President asked for an investigation on October $5^{\text {th }} 2019$ (BRASIL, 2019) and the first official communication from the Environmental Minister to the House of Affairs (OFÍCIO CIRCULAR 1132, 2019) shows that the National Contingency Plan (PNC, in Portuguese) was activated by the Ministry of Environment only on October $11^{\text {th }} 2019$, though it has yet to be fully implemented (Figure 2). The first public hearing that included community representatives in the legislative house was held October $17^{\text {th }}$. Although there are renowned scientists in the Brazilian universities working with modelling and oil dispersion, they were not invited to join the government taskforce (TURRA et al., 2019) until November $16^{\text {th }}$, when government created scientific working groups, with Ad Hoc scientists (GAA, 2019). Lastly, the government failed to prepare and guide the population to minimize environmental damage and prevent damage to public health of areas affected by oil tars, even stating on newspapers and social media that tourists and locals should not be concerned about eating shellfish or other organisms harvested from contaminated beaches (CORDEIRO, 2019). 
Figure 2: Oil spill spots in Brazil Northeast region, and main formal government actions

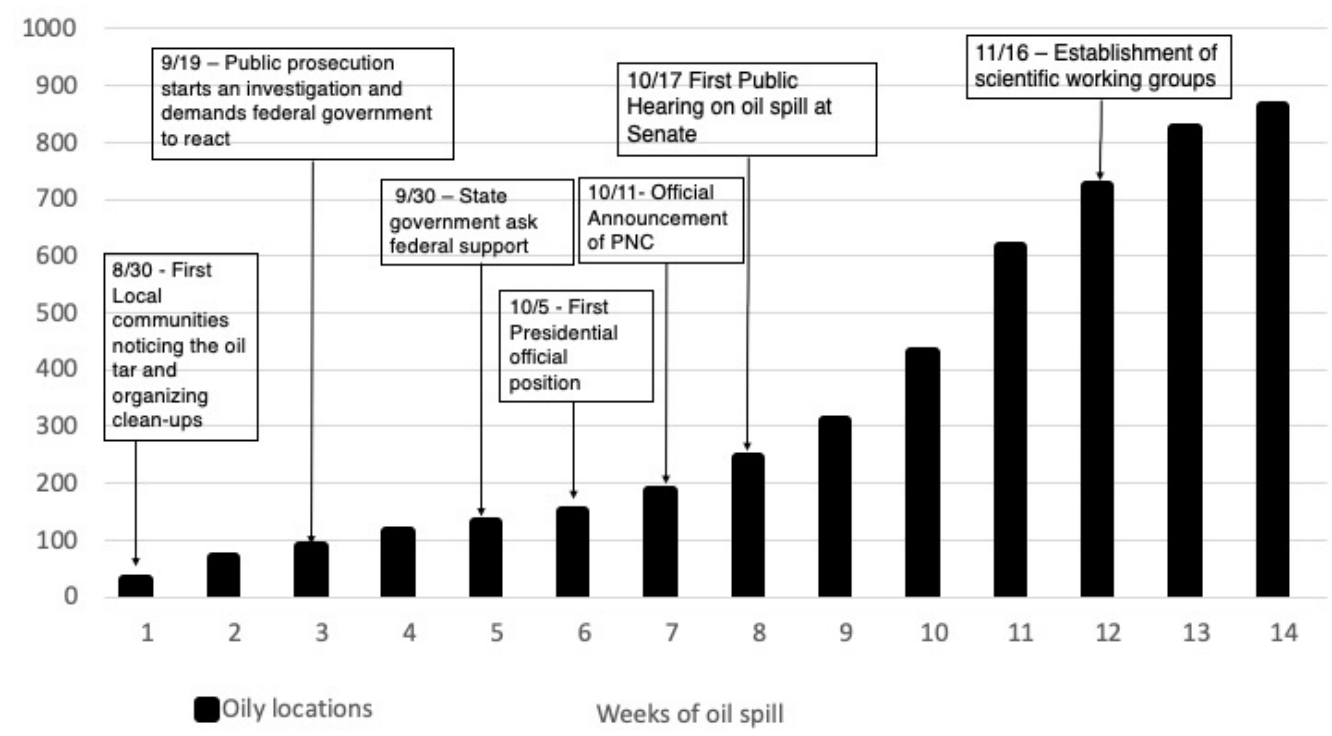

Source: IBAMA, adapted by authors.

\section{International Community}

Another component of the government's information campaign was to place the blame for the spill onto the international community. Current evidence presented by the government points to a foreign vessel moving outside of the Brazilian exclusive economic zone, though not a Greek vessel as the government originally asserted. Thus, initial responsibility for the spill could in fact rest with the International Maritime Organization (IMO) and the related International Convention for the Prevention of Pollution from Ships (MARPOL 73/78). Parties to MARPOL (including Brazil) may enforce the convention in three ways: through vessel inspections to ensure vessels meet minimum technical standards; by monitoring vessel compliance with discharge standards; and by punishing vessels that violate standards. However, MARPOL puts member states in charge of monitoring discharges of oil and, as a consequence, most high seas violators are never caught (MATTSON, 2006), because, typically, member states do not have the resources or interest in patrolling the high seas, nor are Port States allowed to enforce MARPOL requirements outside of their territorial waters.

In other words, even if the vessel that spilled the oil now washing up on Brazil's coast is found, the Brazilian government could not take any action except to request intervention by the country that has jurisdiction over the vessel. This is another level of power disconnect. Identifying oil pollution on the high seas is a wicked problem but technical barriers are not the main roadblock to curtailing the hundreds of spills that happen on the high seas each year. MARPOL member states do not want to give up their sovereignty over their own vessels nor do they want to make shipping more costly 
given the potential economic impact that this could have on importing and exporting states alike. As a signatory country of IMO, the Brazilian government has already stated that it will demand and work for a change in the international system to force all ships to report their positions and activities (MONTEIRO, 2019), but they are not likely to be successful as long as power disconnects prevent the people who are affected by these spills from having much say in MARPOL negotiations. International governance has to enable a bottom-up process to guarantee that the actions from global to local are coherent with social demands. This claim has been incorporated in the Agenda 2030, under the slogan of "leaving no one behind" (UNSDG, 2019), however it is still far to go from paper to practice, and power disconnects are likely to delay or undermine implementation.

\section{Conclusion}

For decades Brazil was portrayed as an environmental leader on the world stage. Caught up in a global backlash, the government is now working to dismantle many of the protections that were put in place by previous administrations. Even major disasters like the oil spill described here or the huge forest fires that ravaged the Amazon did not create sufficient pressure to alter this behavior. This is in part because these disasters are occurring in areas and affecting stakeholders that are politically marginalized and therefore have little ability to affect the current government. Nevertheless, we must also recognize that there are failures of the international community in these cases as well. Lax international regulation of oil pollution does not absolve the Brazilian government of responsibility in this case, but improvements are needed to prevent spills like this from affecting other coastal communities and the biodiversity in the future.

To narrow these power disconnects and respond effectively to disasters like this oil spill, Brazil has to build domestic institutions that guarantee preparedness and responsiveness to environmental emergencies, coordinating across levels and scales with the broad participation of multiple governmental, private, scientific, philanthropic and social movement actors. Internationally, it is imperative to improve enforcement and compliance through a comprehensible system to monitor the international waters. As this involves impacts occurring in a complex social-ecological system which is coupled with critical uncertainties that challenge decision-making, these institutions should be designed for flexibility, reflexivity, and adaptiveness (YOUNG, 2017). Additionally, it is essential to build up response capacity through a crisis emergency fund, trained personnel and a continuous investment in science and technology to enable a modern monitoring system. Regarding oil spill prevention in Areas Beyond National Jurisdictions, Brazil has to develop a strong willingness to participate, engage and be a vocal Global South leader in the multilateral arena. In an environmental crisis like oil spill, there is an opportunity to build institutions, increase social participation, and strengthen international cooperation to narrow power disconnects so that we can prevent or at least mitigate future crises. Ultimately, as long as political injustices persist ecological disasters will continue, and the governance will not improve. 


\section{Acknowledgements}

The authors would like to acknowledge the support of the São Paulo Research Foundation (FAPESP: LRG: 2018/00462-8 and 2019/04481-0) and Brazilian National Council for Scientific and Technological Development (CNPq: AT: Proc. 309697/2015-8 and Proc. 310553/2019-9). The work is part of the activities of the ongoing thematic project, "Environmental Governance in the São Paulo Macrometropolis, due to climate variability" (FAPESP: 2015/03804-9), linked to the FAPESP Global Climate Change Research Program.

\section{References}

ARAUJO et al. Artisanal fishers, consumers and the environment: immediate consequences of the oil spill in Pernambuco, Northeast Brazil. Cad. Saúde Publica 36(1):e00230319. 2020. https://doi.org/10.1590/0102-311X00230319

ASCEMA. Nota Pública dos Servidores Ambientais Federais (MMA, Ibama, ICMBio e SFB) sobre o maior desastre ambiental de vazamento de óleo no Brasil. 2019.

BATISTA, V. Em protesto, grupo de pescadores invade sede do Ibama em Salvador. Correio Braziliense. $22^{\text {nd }}$ of October 2019. Available at: https://www.correiobraziliense.com.br/app/noticia/brasil/2019/10/22/interna-brasil,799880/em-protesto-grupo-de-pescadores-invade-sede-do-ibama-em-salvador.shtml Accessed on: October, 2019.

BRASIL. Despacho Do Presidente Da República. Diário Oficial Da União. Publicado em: 05/10/2019 | Edição: 193-B | Seção: 1 - Extra | Página: 1 Órgão: Presidência da República/ Despachos do Presidente da República

CORDEIRO. 'O peixe é um bicho inteligente. Quando vê óleo, foge', diz secretário da Pesca. Estadão. $1^{\text {st }}$ of November 2019. Available at: https://sustentabilidade.estadao.com.br/noticias/geral,o-peixe-e-um-bicho-inteligente-quando-ve-oleo-foge-diz-secretario-da-pesca,70003072405 Accessed on: November, 2019.

DIARIO DO NORDESTE. Manchas de óleo detectadas em litoral do Nordeste continuam sob investigação, diz Marinha do Brasil. Diário do Nordeste. 30th of June 2020. Available at: https://diariodonordeste.verdesmares.com.br/metro/manchas-de-oleo-detectadas-em-litoral-do-nordeste-continuam-sob-investigacao-diz-marinha-do-brasil-1.2961140 Accessed on: August, 2020.

GAA. Nota à imprensa sobre os grupos de trabalho. 2019. Available at: https://www.marinha. mil.br/sites/default/files/nota_gaa_16nov___coordenacao_cientifica_do_gaa_1.pdf Accessed on: November, 2019.

IBAMA. Manchas de óleo no litoral do nordeste. 2019. Latest update 21st of October 2019. Available at: https://www.ibama.gov.br/notas/2047-manchas-de-oleo-no-litoral-do-nordeste Accessed on: October, 2019. 
MAGRIS, R.A; GIARRIZZO, T. Mysterious oil spill in the Atlantic Ocean threatens marine biodiversity and local people in Brazil. Mar. Pollut. Bull. 153, 110961. 2020. https://doi.org/10.1016/j. marpolbul.2020.110961

MATTSON, G. MARPOL 73/78 and Annex I: An Assessment of its Effectiveness, Journal of International Wildlife Law and Policy, 9:2, 175-194, 2006. DOI: 10.1080/13880290600728195

MONTEIRO, T. Almirante compara óleo em praias a 'bombardeio' e diz que investigação mira navio irregular. Estadão. 22nf of October 2019. Available at: https://sustentabilidade.estadao. com.br/noticias/geral,almirante-compara-oleo-no-nordeste-a-bombardeio-e-diz-que-investigacao-mira-navio-irregular,70003059831 Accessed on: October, 2019.

OPEN LETTER FROM CIVIL SOCIETY. Carta Aberta sobre a Ocorrência de óleo no litoral brasileiro. 2019. Available at: http://www.observatoriodoclima.eco.br/ongs-pedem-fim-de-sigilo-sobre-acoes-contra-oleo-no-nordeste/ Accessed on: 29 October 2019.

ROSSI, A. Bolsonaro presidente: Sudeste e Sul têm peso decisivo na eleição ao darem 6,5 milhões de votos a menos ao PT. 29th of October 2018. Available at: https://www.bbc.com/portuguese/brasil-45997474 Accessed on: 29 October 2019.

SOARES et al. Oil spill in South Atlantic (Brazil): Environmental and governmental disaster. Mar. Policy 115. 2020. https://doi.org/10.1016/j.marpol.2020.103879

TURRA et al. Chorar sobre o óleo derramado não reduz os danos à zona costeira. Estadão. $18^{\text {th }}$ of October 2019. Available at: https://opiniao.estadao.com.br/noticias/espaco-aberto,choro-sobre-o-oleo-derramado,70003054292 Accessed on: October, 2019.

UNSDG. Leaving No One Behind: A UNSDG Operational Guide For Un Country Teams (Interim Draft). 2019. Available at: https://undg.org/document/leaving-no-one-behind-a-unsdg-operational-guide-for-un-country-teams-interim-draft/ Accessed on: December 2018.

VIOLA, E.; GONÇALVES, V. K. Brazil ups and downs in global environmental governance in the 21st century. 2019. Revista Brasileira de Política Internacional, 62(2). http://dx.doi. org/10.1590/0034-7329201900210

WALKER et al. Communication practices for oil spills: Stakeholder engagement during preparedness and response. Human and Ecological Risk Assessment: An International Journal, 21(3), 667-690. 2015.

WEBSTER, D. G. The action cycle/structural context framework: a fisheries application. Ecology and Society (20)1: 33. 2015. http://dx. doi.org/10.5751/ES-07272-200133

YOUNG, O. Governing Complex Systems. The social capital for the Anthropocene. The MIT Press. Cambridge, Massachusetts. 2017. 267pp. 
Leandra R. Gonçalves

$\square$ goncalvesleandra@gmail.com

ORCiD: https://orcid.org/0000-0003-1182-418X
Submitted on: 07/05/2020

Accepted on: 29/06/2020

2020;23:e0077

\title{
DG Webster
}

D.G.Webster@dartmouth.edu

ORCiD: https://orcid.org/ 0000-0002-8368-983X

\section{Oran Young}

$\square$ oran.young@gmail.com

ORCiD: https://orcid.org/0000-0003-2463-6735

\section{Marcus Polette}

$\square$ mpolette@univali.br

ORCiD: https://orcid.org/0000-0003-0437-4205

\author{
Alexander Turra \\ ఐturra@usp.br \\ ORCiD: https://orcid.org/0000-0003-2225-8371
}

How to cite: GONCALVES, L.R.; WEBSTER, DG; YOUNG, O.; POLETTE, M.; TURRA, A. The Brazilian Blue Amazon under threat: Why has the oil spill continued for so long?. Ambiente \& Sociedade. São Paulo, v. 23, p. 1-11, 2020. 


\title{
Amazônia azul brasileira ameaçada: por que o derramamento de óleo continuou por tanto tempo?
}

\author{
Leandra R. Gonçalves \\ DG Webster \\ Oran Young \\ Marcus Polette \\ Alexander Turra
}

São Paulo. Vol. 23, 2020

Ideias em debate
Resumo: Em agosto de 2019, um incidente com derramamento de óleo atingiu a costa do Brasil, afetando algumas das praias mais visitadas e preservadas do país no Nordeste e Sudeste. Este artigo argumenta que a influência da desconexão de poder atrasou as ações apropriadas. As desconexões de poder ocorrem quando as vítimas de dano ambiental (residentes do nordeste e sudeste do Brasil) não têm poder para evitar o dano ou, inversamente, quando aqueles que têm o poder de proteger o meio ambiente (governo brasileiro e comunidade internacional) não enfrentam os custos da degradação. Embora o Brasil tenha emergido como líder ambiental na arena internacional no passado, deixou a desejar na atuação e proposição de melhorias necessárias para impedir que derramamentos como esse afetem outras comunidades costeiras e a biodiversidade no futuro. Por fim, enquanto persistirem as injustiças políticas, os desastres ecológicos continuarão e a governança não será aprimorada.

Palavras-chave: Vazamento de petróleo, desconexão de poder, Brasil

Como citar: GONCALVES, L.R.; WEBSTER, DG; YOUNG, O.; PO. LETTE, M.; TURRA, A. Amazônia azul brasileira ameaçada: por que o derramamento de óleo continuou por tanto tempo?. Ambiente $\mathbb{E}$ Sociedade. São Paulo, v. 23, p. 1-11, 2020. 


\title{
La Amazonia azul brasileña amenazada: ¿por qué ha continuado el derrame de petróleo durante tanto tiempo?
}

\author{
Leandra R. Gonçalves \\ DG Webster \\ Oran Young \\ Marcus Polette \\ Alexander Turra
}

São Paulo. Vol. 23, 2020

Ideas en Debate
Resumen: En agosto de 2019, un incidente de derrame de petróleo arrasó la costa de Brasil y afectó a algunas de las playas más visitadas y preservadas del país en el noreste y sureste. Este artículo argumenta que la influencia de las desconexiones de poder retrasó las acciones adecuadas. Las desconexiones de poder ocurren cuando las víctimas de daños ambientales (residentes del noreste y sureste de Brasil) carecen de poder para evitarlo o, por el contrario, cuando quienes tienen el poder de proteger el medio ambiente (el gobierno brasileño y la comunidad internacional) no experimentan costos de degradación. Aunque Brasil se ha convertido en un líder ambiental en el ámbito internacional en el pasado, ha estado detrás de lo esperado y las mejoras que se necesitan para evitar que derrames como este afecten a otras comunidades costeras pobres y a la biodiversidad en el futuro. Finalmente, mientras persistan las injusticias políticas, los desastres ecológicos continuarán y la gobernanza no mejorará.

Palabras-clave: Derrame de petróleo, desconexiones de poder, Brasil

Como citar: GONCALVES, L.R.; WEBSTER, DG; YOUNG, O.; POLETTE, M.; TURRA, A. La Amazonia azul brasileña amenazada: ipor qué ha continuado el derrame de petróleo durante tanto tiempo?. Ambiente $\&$ Sociedade. São Paulo, v. 23, p. 1-11, 2020. 